
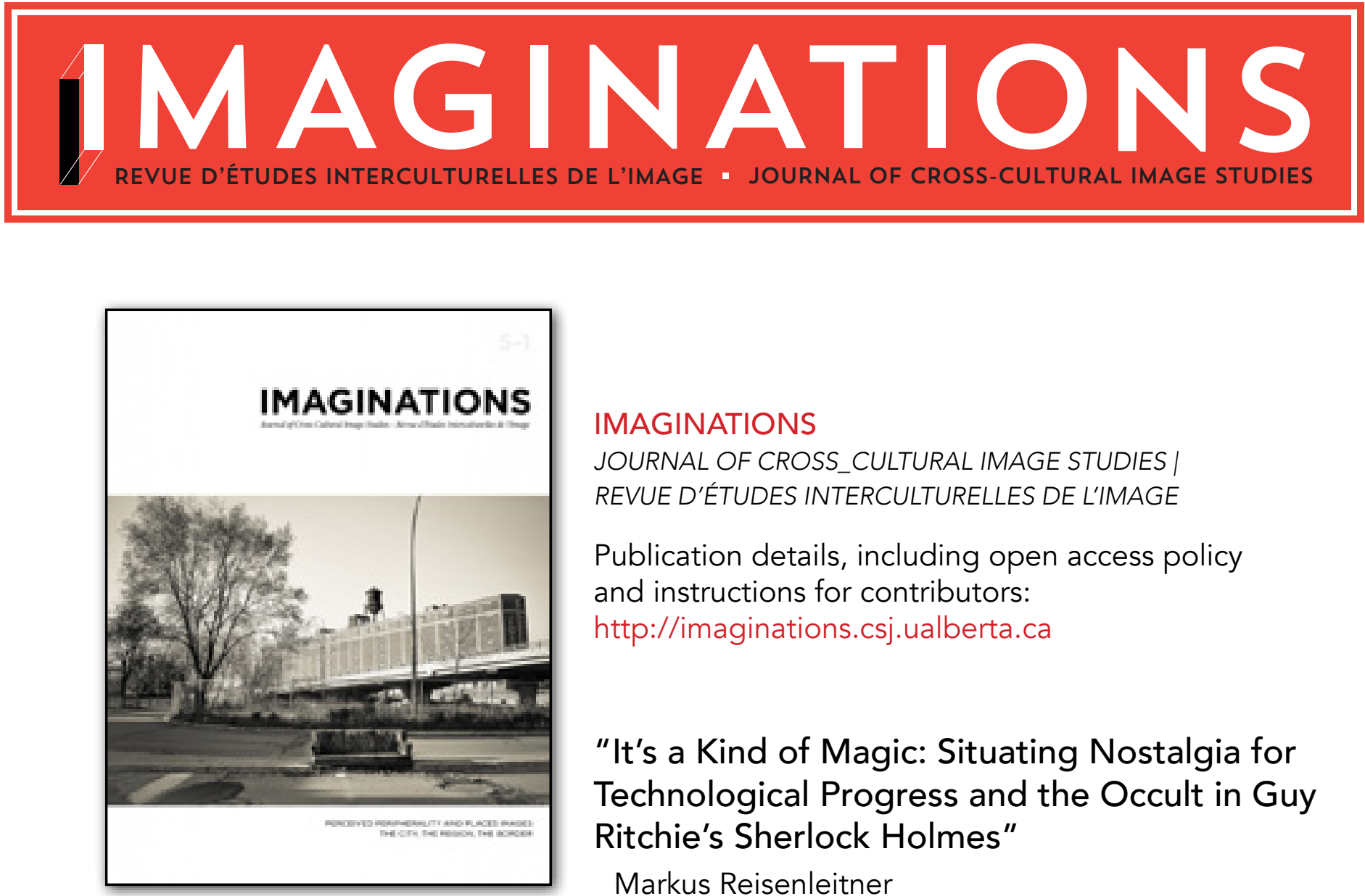

IMAGINATIONS
JOURNAL OF CROSS_CULTURAL IMAGE STUDIES |
REVUE D'ÉTUDES INTERCULTURELLES DE L'IMAGE

Publication details, including open access policy

and instructions for contributors:

http://imaginations.csj.ualberta.ca

"It's a Kind of Magic: Situating Nostalgia for Technological Progress and the Occult in Guy Ritchie's Sherlock Holmes"

Markus Reisenleitner

March 28, 2014

To Cite this Article:

Reisenleitner, Markus. "It's a Kind of Magic: Situating Nostalgia for Technological Progress and the Occult in Guy Ritchie's Sherlock Holmes" Imaginations 5:1 (2014): Web (date accessed) 122-134. DOI: 10.17742/IMAGE.periph.5-1.9

To Link to this article:

http://dx.doi.org/10.17742/IMAGE. periph.5-1.9

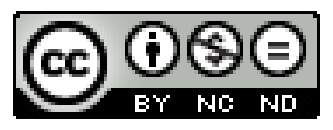

The copyright for each article belongs to the author and has been published in this journal under a Creative Commons Attribution NonCommercial NoDerivatives 3.0 license that allows others to share for non-commercial purposes the work with an acknowledgement of the work's authorship and initial publication in this journal. The content of this article represents the author's original work and any third-party content, either image or text, has been included under the Fair Dealing exception in the Canadian Copyright Act, or the author has provided the required publication permissions. 


\section{IT'S A KIND OF MAGIC: SITUATING NOSTALGIA FOR TECHNOLOGICAL PROGRESS AND THE OCCULT IN GUY RITCHIE'S SHERLOCK HOLMES MARKUS REISENLEITNER | YORK UNIVERSITY}

Guy Ritchie's recent blockbuster success with a revisionist Sherlock Holmes is the latest in a series of popular films and fiction to have reinvigorated a nostalgic imaginary of London's past that places the former capital of the Empire at the crossroads of a persistent Manichean battle between empiricist-driven technological progress and traditions of occult knowledge supposedly submerged in the 17th century yet continuing to trickle into the heart of the Empire from its colonies. By tracing some of these historical layers sedimented into 21st-century popular imaginaries of London's past, this paper explores the mechanisms of popular culture's production of nostalgia that mediate public memories and histories and suture them to the imaginary urban geographies that constitute the space of the global city through its metonymic sites and its materialized histories.
Le succès récent du blockbuster de Guy Ritchie revisitant la figure de Sherlock Holmes s'inscrit dans une lignée récente de films et de récits populaires qui ont revivifié un imaginaire nostalgique du passé londonien dans lequel le centre de l'ancien empire britannique se trouve au croisement d'un conflit manichéen entre un progrès scientifico-technologique et les traditions d'un savoir occulte supposément enfouis dans les siècles précédents mais qui continue à s'insinuer au cœur de l'empire à partir de ses colonies. En retraçant certaines de ces couches historiques dans les recréations contemporaines du Londres impérial, cet article explore les mécanismes de production de la nostalgie dans la culture populaire en tant qu'ils font le pont entre la mémoire publique et la mémoire historique en rattachant celles-ci à un imaginaire de la géographie urbaine qui pour sa part pointe vers la ville globale d'aujourd'hui. 
In the $21^{\text {st }}$-century competition between global cities to establish themselves as central, London has emerged as a clear front-runner. London has been cementing its position, asserted since the opening up of its stock market in 1986, not only by economic and political decisions but also through a slew of representational practices, most recently through the global media spectacle of the opening of the 2012 Olympic games (Reisenleitner 2014). The very contemporary imaginary of London's centrality to a global system of urban nodes has routinely been buttressed by a particular vision of empire, an almost desperate attempt to create (or recreate) the collections and constellations of collective memories that would otherwise be rapidly obliterated in the constant need to assert global-city status through "nowness," creative destruction and innovation. Mediated memory of empire has been mobilized to provide an imagined historical context for the single-minded "branding" campaigns of ad agencies, global media spectacles and similar vehicles powered by the engine of global market fundamentalism, a hegemonic practice that imposes stability and homogeneity on a space (the urban) that, as Steve Pile reminds us, “... cannot be thought of as having one geography and one history" (Pile, Brook, and Mooney vii).

In this article, I explore some of the historical layers sedimented into 21 stcentury popular imaginaries of London's past. I am specifically interested in a persistent dichotomy of technology vs. occult knowledge that seems to be intimately connected to the persisting imaginary of London as a global city. I argue that this imaginary has become the basis of a nostalgia for the British Empire, one that mediates public memories and histories and sutures them to the imaginary urban geographies that constitute the space of the global city through its metonymic sites and its materialized histories. I will explore how cinematic techniques, specifically the possibilities of computer-generated images, negotiate the visual memories of London as a centre of empire in Guy Ritchie's Sherlock Holmes (2009). Placing the movie in its genre context and exploring the layered histories that inform the film's take on the urban detective can reveal the constitutive elements that challenge and inform the imaginary of London's centrality in contemporary Hollywood-mediated popular culture.

\section{Policing the Imperial Centre}

The emergence of popular culture produced for a mass audience coincides with the emergence of the modern city during the nineteenth century. European and North American popular culture developed in constant dialogue with the profoundly unsettling experiences of modernity, imperialism, and globalization. The upheavals that accompanied urbanization resulted in new ways of seeing the city as opaque and potentially dangerous; an alleged illegibility of the city and the urban masses translated into popular fiction as crime and threat associated with the city streets and translated into the architectural forms of gated communities, ubiquitous surveillance, 
defensible architecture, and all the other accoutrements of a city of fear that Mike Davis so masterfully conjures up in City of Quartz (Davis 1990). "Modern" ways of seeing the city, and acting upon the city, arose with the nineteenth-century city of industrialism and its immiserated working class and resulted in the city being seen as a "problem" (similar to the emergence of the "environment" as a problem in the later twentieth century). The necessity of rendering this problematic city-the site of crime and illness (often expressed through body metaphors)-administrable is predicated on the visibility of the city as an object. While urban planners and reformers were busy re-imagining the city as a cleansed, controlled and sanitized machine for living (Corbusier), working, traffic flow, and commerce, the fear of the irruption of the uncanny into city spaces that defy planning and description has continued to speak to the presence of an elusive other-often a colonial other-in the Western metropolis. Popular genres like detective fiction and film noir have created topographies of modern urbanity in which monstrous spaces, characterized equally by the danger and lure they pose for the metropolis, threaten an assumed movement towards a wellordered urban rationality, establishing (at least Western) urbanity as a structure metaphorically and literally built on the (post-)imperialist paranoia about the presence/return of the alien and asserting a desire to establish control over fundamentally unstable spaces-precisely the kind of control that also resulted in the disciplining narratives of urban surveillance, statistics and reform. Eugène
Sue's histories in theMysteries of Paris are as responsible for Baron Haussmann's reimagining (and redrawing) of Paris as John Fante (Ask the Dust; Dreams from Bunker Hill) was for Los Angeles's "Bunker Hill Renewal Project"—even Los Angeles was, in Orson Welles's words, "[i]n the beginning [...] simply a 'bright, guilty place' without a murderous shadow or mean street in sight" (Davis 2001, 33). Anthony Vidler draws our attention to the historical roots of sensitivities that have become commonplaces in contemporary popular culture:

The contemporary sensibility that sees the uncanny erupt in empty parking lots around abandoned or run-down shopping malls, in the screened trompe d'oeil of simulated space, in, that is, the wasted margins and surface appearances of postindustrial culture, this sensibility has its roots and draws its commonplaces from a long but essentially modern tradition. Its apparently benign and utterly ordinary loci, its domestic and slightly tawdry settings, its ready exploitation of an already jaded public, all mark it out clearly as the heir to a feeling of unease first identified in the late eighteenth century. (Vidler 3)

This feeling of unease and threat that accompanied the emergence of the modern city, and its symbolic resolution through the re-establishment and imposition of a rational order, is epitomized by the emergence of the figure of the urban detective, arguably the most important figure in the history of urban perception. Like the flâneur-detached, interested, fascinated, trying to make sense of the city but with what Simmel 
described as a blasé attitude (14) — the detective has become a privileged site of Western urban perception, the solitary (often staunchly middle-class) male figure entitled to move through the metropolitan maze of illegible, violent and dangerous crowds to decipher what needs deciphering in order to tame, appropriate and control. Tony Bennett, drawing on Benjamin, reminds us that "the development of a position of imaginative spectatorial dominance afforded by detective fiction was accompanied by, and corresponded to, the development of new mechanisms of surveillance whichprecisely through their bureaucratic reduction of individuality to a set of knowable traces-rendered the city legible to the gaze of power" (215). The urban detective's way of acting on the city is informed by the superior insight afforded by the rationality that distinguishes him from the urban crowd while also legitimating his exerting violence on the city and its less desirable elements. The urban detective has come to stand for the urban planner and the bulldozer conflated into one, ultimately containing the unruly cityscape (and the unruly crowd moving through it) by exerting some form of visual/semiotic control. Detective fiction has come to function as a

fantasy of a spectatorial subjectivity capable of establishing epistemological and aesthetic control over an environment commonly perceived to be threatening and opaque. By reducing the city to a legible model or emblem of itself, and by demonstrating his control over its production, such a subjectivity assumes a paternalistic or heroic role in relation to an urban literary audience. (214)
Detective fiction as "representational forms of solutions to the problems of social control in a dynamic capitalist urban milieu" (Frisby 58) draws attention to the fact that the meaning of a city is produced as a site of social negotiations (which are not private but collective, situated practices), "an imaginary space created and animated as much by the urban representations to be found in novels, films and images as by any actual urban places" (Donald $\mathrm{x}$ ).

Sherlock Holmes, together with Edgar Allan Poe's Dupin, is the archetypal detective of the Western metropolis, on mission after mission to uphold the city's rational order, moving through the metropolitan maze of illegible, violent, dangerous and exotic crowds, rationally deciphering what is illegible in order to establish a "rational" form of order and control, often violently and through superior physical prowess. Holmes has recently been resurrected in a variety of fiction, film and TV adaptations that highlight London's presence on the global media stage. Guy Ritchie's 2009 and 2011 blockbuster successes (Sherlock Holmes and Sherlock Holmes, a Game of Shadows) with a revisionist Sherlock Holmes as a down \& dirty Iron Man-like action hero in what set out to become, according to producer Joel Silver, "an 1891 Bond film" (a sentiment that highlights the connection of the two major popular culture heroes to the violence of empire), are major contributions to a series of popular movies and fiction to have reinvigorated a nostalgic imaginary of London's past. 
The plot of Sherlock Holmes (2009) revolves around the eponymous detective, played by a somewhat seedy but superfit Robert Downey Jr, and his stalwart sidekick Watson, played by Jude Law, who prevent the megalomaniac sorcerer and magician Lord Blackwood (Mark Strong) from blowing up Parliament and reclaiming and recolonizing America for the British Empire. They are joined by the feisty Irene Adler (Rachel McAdams), remembered by Holmes fans from Arthur Conan Doyle's first short story, the 1891 "A Scandal in Bohemia," as the only woman able to outsmart Holmes. Together they pursue the evil mastermind in a ride that involves numerous actionand fight scenes in paradigmatic London locations such as Baker Street, the Embankment, the shipyards of the East End's docklands, the sewers, and, in the climactic finale, on a Tower Bridge under construction-a half-finished symbol of the Empire's technological prowess that connects the proletarian outskirts of the river's southern bank to the metropolitan centre but also literally controls the flow of ship traffic (by raising the bridge) from and to its colonies around the world.

Guy Ritchie's knowing update of the Baker Street sleuth inserts itself into the generic conventions of more than one and a half centuries of detective stories. Robert Downey's character might be more physical than previous versions (enjoying, not unlike the film's director and lead, the occasional drunken brawl in an Irish pub) - something Ritchie has justified including in his film by pointing to the original stories, in which Holmes is often depicted boxing, sprinting, and disguising himself on chases. However, the lineage is very clear. Packaged into Downey's character are not only Doyle's and Sax Rohmer's detectives but also Poe's "Man of the Crowd" and Baudelaire's flâneur-he is a dandy, a ragpicker, and a sloppy Bohemian. Ritchie's protagonist knows his city-the London of 1891so well that there is literally no pulling the wool over his eyes: when taken blindfolded to the Temple of the Four Orders, an occult-dabbling secret society headed by a prominent Lord, he "was admittedly lost for a moment between Charing Cross and Holborn, but was saved by the breadshop on Saffron Hill, the only baker to use a certain French glaze on their loaves, a Brittany sage. After that carriage fork left and right ..."

Local knowledge and easy movement through every social layer of the cityincluding its underground, the sewersmake it possible for him to keep at bay the forces that threaten the metropole's rational social order. Following generic conventions, the material city is presented as a semiotic reservoir to be deciphered. Clues are spread throughout the urban landscape, and solving this puzzle through powers of intellect is the detective's forte, but he is also in perfect command of all the other institutions of modernity, particularly those of movement:

The deep anxiety of an expanding society: the fear that development might liberate centrifugal energies and thus make effective social control impossible. This problem emerges fully in the metropolis, where anonymity - that is, impunitypotentially reigns and which is rapidly becoming a tangled and inaccessible 
hiding place. We have seen detective fiction's answer to the first problem: the guilty party can never hide in the crowd. His tracks betray him as an individual, and therefore a vulnerable, being. But detective fiction also offers reassurance on the second point. All Holmes's investigations are accompanied and supported by the new and perfect mechanisms of transportation and communication. Carriages, trains, letters, telegrams, in Conan Doyle's world, are all crucial and always live up to expectations. They are the tacit and indispensable support of the arrest. Society expands and becomes more complicated: but it also creates a framework of control, a network of relationships, that holds it more firmly together than ever before. (Frisby 58)

In the detective genre, command and control of modern technology are equated with mastery of the urban. This is how crimes are solved, and order reestablished.

\section{Hermetic Historicities}

The resolution of threats to the urban more often than not involves exorcizing (violently and physically) the threat of a colonial "other." However, while a Chinese villain does make an appearance in a fight scene-a clear reference to Sax Rohmer's Fu Manchu-, the threat posed by evil mastermind Lord Blackwood and his esoteric cult do not fit neatly into the pattern of threats to the colonial centre described above. With his vaguely foreign looks and sounds and references to old Egyptian and Cabalistic teachings, Blackwood might be read as an orientalized representative of a colonial outside threatening the imperial centre, but this would disregard his being positioned very clearly within an English tradition of occultism. The figure of Lord Blackwood is recognizably modeled after the influential and controversial English occultist and magician Aleister Crowley (1875-1947),

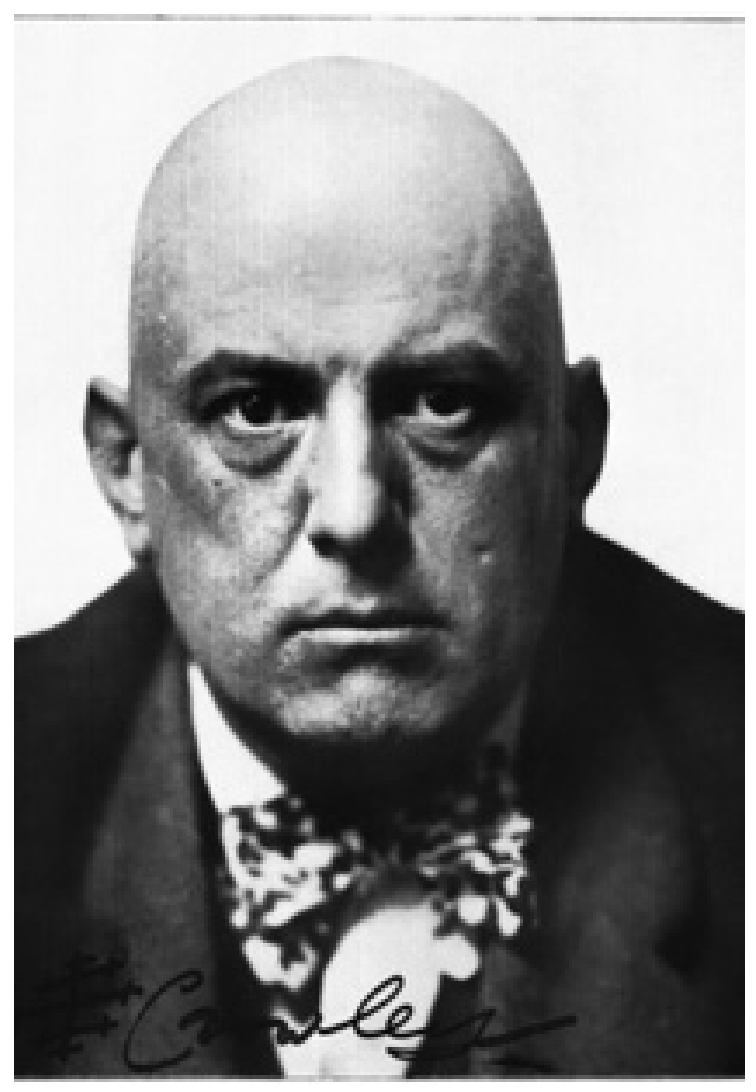

Fig. 1 Aleister Crowley

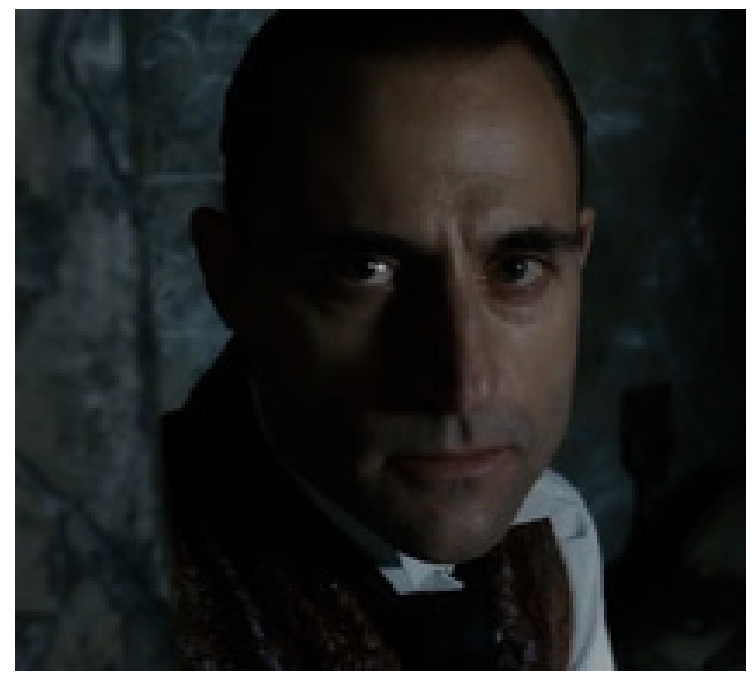

Fig. 2 Lord Blackwell 
who was involved in a number of early twentieth-century hermetic and esoteric groups not too dissimilar from Ritchie's fictional "Temple of the Four Orders" (see Pasi). While some of this occult practice is presented as being of oriental origin, it is all really a quite silly mixture of elements from the Christian, Jewish and Egyptian traditions, in other words: a merry gumbo of "Western Civilization"'s past that has, mysteriously, left its obscure traces in the material shape of the city. Holmes manages to make sense of this past, and prevent catastrophe, by mapping this "ancient" knowledge-manifested in London's urban morphology.

Uncovering some past secret is, of course, nothing unusual for detective fiction. What is, however, surprising in these twenty-first century recuperations of the historical is that in addition to predictably hearkening back to the modernist strands of the late nineteenth- and early-twentieth century that gave rise to a genre linking technological rationality and empire, current manifestations of the historical in popular culture seem to throw into relief what is perceived as an almost Manichean struggle between empiricist-driven technological progress and traditions of occult knowledge supposedly submerged in the seventeenth century.

What obviously springs to mind in this otherwise mind-boggling denouement of an ancient conspiracy manifesting itself in the heart of empire is Dan Brown's megahyped $\mathrm{Da}$ Vinci Code and the previously written (2000), although only recently filmed (2008)Angels and Demons. Like Guy Ritchie's Sherlock Holmes, the Da
Vinci Code's symbologist professordetective Robert Langdon deciphers historical symbols to reveal ancient mysteries passed on through medieval and Renaissance channels of conspiracies and physically preserved in the cities' material environments, breathlessly connecting dots on the maps of Paris, Rome and London in order to uncover Gnostic traditions preserved in secret societies. For Dan Brown, the historical city also provides the crucial clue for unraveling the ancient mystery. Much like Sherlock Holmes's deductions or Dupin's ratiocinations, the instruments of the professor's intellectual toolbox reveal "correct" interpretations of those clues that ultimately lead to modernist rational closure-in Brown's case, a deep structure of an alternative narrative of Christianity, and thus European civilization, that does away with the contingency and multifacetedness of history's relics and assigns, literally, the right "place" to historical manifestations. Dan Brown's story similarly follows the well-established generic metaphor of the city as a historically layered enigma whose underlying deep structure-the historical narrative that manifests itself in highly visible material symbol carriersneeds to be deciphered by the expert. The plot of The Da Vinci Code is structured as a treasure hunt, with clues hidden in well-known art works and tourist sites. The structure hidden behind all the superficially confusing manifestations of history is conveniently provided by the heavy hand of the Catholic Church - the most persistent, organized and powerful Euro-global institution in the history of the West and arguably the originary 
motor for the establishment of global domination and empire, represented in Brown's novel by its more recent hardliner manifestation, the Opus Dei (established in 1928), and its equally monolithic "other," the secret society that preserved the hidden knowledge of the "sacred female."

The metonymic London locations that Dan Brown chooses for resolving the contradictions between science and religion, such as Westminster Abbey, provide closure in ways vaguely similar to Dame Francis Yates' historical trajectory of Elizabethan and seventeenthcentury London's role as a funnel for articulations of empiricism and occult knowledge culminating in both open and submerged agendas of the Royal Society (Yates 1964, 1972, 1979). According to Yates, the Renaissance marriage of magic and science, which was based on Cabalistic and Hermetic teachings imported from Italy, epitomized by the magician Prospero in Shakespeare's The Tempest, and which thrived during the formation of the British imperialist tradition during Queen Elizabeth's I. reign, was submerged by the institutions of modern science, yet continued to inform knowledge production in the imperial centre. Condensing this tradition into the role of Isaac Newton, Brown efficiently mobilizes the reverberations of new-age inspired historical narratives that pick up on hypotheses of occult, supposedly ancient knowledge's lineages having been preserved by secret societies. The persistence of history ultimately guarantees meaning and reveals its overdetermined and wildly psychoanalytic origin: the tomb of Mary Magdalene beneath the Louvre. Brown's narrative thus operates much like a tourist map: once properly unfolded (and only a select few have access to this particular gift), everything falls into place. The detective unfolds the bizarre traces of history in the material urban environment into a linear (albeit implausible and preposterous) narrative.

Sherlock Holmes in Guy Ritchie's interpretation is very much part of the same tradition, but takes as its focus the struggle against and submersion of ancient occult knowledge during the Industrial Revolution. The occult knowledge that threatens the metropole here is presented as already having been part of the Rule Britannia lineage, and consequently the evil master plan is not an overthrow of the British Empire through some foreign (previously often vaguely oriental) enemy (as would have been mandated by generic tradition), but rather the re-creation of an authoritarianimperial tradition that includes the United States, precisely by mobilizing the submerged occult. "It looks like he was attempting to combine occult practice with scientific formula," states Holmes when he finally figures out Blackwood's intentions, but "there was never any magic, only conjuring tricks." Ultimately, it is technological rationality that has the last say. The occult only consists of recycling earlier scientific knowledge, such as an "ancient Egyptian recipe" for untraceable poisons. In the final climactic fight sequence, Blackwood is not killed by Holmes but by the half-finished Tower Bridge itself: technological symbol of 
the city's connection to the global traffic rationalization of empire.

What Guy Ritchie is picking up on here is the well-known Victorian penchant for the occult and the paranormal-after all, Arthur Conan Doyle was a wellknown spiritualist. In an exclusively Blu-ray special feature Guy Ritchie takes us through the movie like a budding film professor, explaining that "the intersection of this particular time of science and superstition... is what this era is about." While this commentary seems to be stating the obvious, the filmic recuperation of this history also involves reclaiming the East End and other places in London through representations of the occult, a way to layer and deepen the histories of many sites in London. Indeed, Ritichie's attention to sites is meticulous, with a heavy emphasis on the "authenticity" of the recreation of 1891 London. This creation of historical authenticity necessitated shooting at non-London sites such as the docklands of Manchester, not yet gentrified into a Canary-Wharf like corporate YuppieTown, and numerous digital effects-in other words, a cinematographic toolkit better suited to (re-)create urban history than the irrevocably altered material city. It is the role of the digital in filmmaking that reclaims certain histories that I would like to turn my attention to next.

\section{Role of the Visual-Digital}

The visual design of Sherlock Holmes is meant to painstakingly recreate the London of 1891, clearly along visual lines of representation that take their cues from Sidney Edward Paget's illustrations of Conan Doyle's stories for the Strand magazine. Ritchie is therefore bypassing a long tradition of cinematic versions of Sherlock Holmes that have created very different, crossreferenced imaginaries of turn-of-thecentury London. The Sherlock Holmes film coming closest to Guy Ritchie's urban imaginary is a Steven Spielberg production of 1985, Young Sherlock Holmes, which also features an esoteric underground cult supposedly originating in Egypt, and notable mostly for its computer-generated effects, including the first fully computer-generated character: a knight in a stained glass window, created by Lucasfilm's John Lasseter, of Toy Story (1995) fame.

Digital technologies in film-making have clearly come a long way since 1985 , giving filmmakers the means to generate images and sounds of the past that are infinitely malleable and able to eschew the archival and material traces of the moment of film-making, while at the same time making it possible to create pasts remembered through a lineage of images. Films such as Sky Captain and the World of Tomorrow (2004, d. Kerry Conran) and King Kong (2005, d. Peter Jackson) were shot entirely against blue/ green screen on sound stages in an attempt to visually recreate pasts through their mediations by cinematic images (see Reisenleitner 2012). Guy Ritchie's film, however, while obviously using compositing techniques and digital special effects technology liberally for his streetscapes, fight scenes, explosions, etc., very deliberately includes "real places," location shots which were digitally 
enhanced but still meant to produce a form of "authenticity" supposedly denied to the purely digital. While the recreation of the Docklands was actually filmed in Manchester and Liverpool, Ritchie seems eager precisely not to eschew the material traces of the urban histories of the imperial centre into which his narrative inserts itself. The material remnants, the ruins of an empire driven by mechanization and an industrialist rationality, make their way into shots of a huge shipyard and a mechanized slaughterhouse in the Docklands; the centre of British rule-Parliament-is metonymically presented by Manchester Town Hall; and the occultist heritage is present in a shot of Covent Garden's Freemason's Hall. The scenes most reliant on CGI are the panoramic views from Tower Bridge under construction during the final showdown, when the visual referents shift from recreating historically accurate contexts of still existing places through CGI to a visuality more reminiscent of Gustave Dorés and Paget's illustrations.

\section{Conclusion}

Andrew Ross reminds us that it is not only space but also time that has become fluid in techno-simulation (132). It seems to me that the centrality of digital production methods in Ritchie's film is predicated precisely on this aspect of the fluidity of time, its nexus to the materiality of the physical, specifically urban environment, and a desire to render the memory images of the potentialities of the past, whose material traces have been erased by natural and man-made disasters. Like the computer-generated fractal weather maps and other CG-generated special effects through which movies like The Day After Tomorrow (2004, d. Roland Emmerich) have envisioned the weather, a system as unimaginably complex as the past, and with similar effects on material environments, digitally modified images re-constitute historicities that have, precisely because they have become disconnected from materiality, transcended experiential thresholds. Digital simulation, because it is infinitely malleable, visualizes an approach to the past in which "chronological topographies replace constructed geographical space, where immaterial electronic broadcast missions decompose and eradicate a sense of place" and allow us to come to terms with the disconcerting consequences of what Abbas (personal communication) describes as the "urban double-take," the sensation that when you look again, the complexity of the system has already changed your perception, so the only thing you can see is the pre-conceived cliché-nostalgia-as the only, albeit alternate, chronology possible. Digital cinematography seems to manage to capture the oneiric quality necessary to imagine (urban) pasts in their global connectivity and multi-layered temporal synchronicity, the mise-en-scène of past possibilities for the future.

The Tower Bridge sequence captures the oneiric quality of the Empire through what was one of its most prominent structures. It becomes Ritchiess symbol of a London at the heart of a British-ruled world of technological progress from which the esoteric is (repeatedly) purged. But it is also a fragile, half-finished 
structure, and clearly a nostalgic, visually mediated memory of an empire that never was. The surviving material city that Ritchie takes great effort to include in his film does not seem to allow for the compositing out of powerful challenges to the (Western) forces of rationality in the same way, and we are left expecting the unavoidable sequel, which hit cinemas during a holiday that is surely one of Western Civilization's most powerful reminders of its pagan past: Christmas (2011).

\section{Works Cited}

Baudelaire, Charles. The Painter of Modern Life: And Other Essays. London: Phaidon; distributed by New York Graphic Society Publishers, Greenwich, Conn., 1965. Print.

Bennett, Tony. Popular Fiction: Technology, Ideology, Production, Reading. London, New York: Routledge, 1990. Print.

Brown, Dan. Angels \& Demons. New York: Atria Books, 2003. Print.

---. The Da Vinci Code. New York: Doubleday, 2003. Print.

Conran, Kerry et al. Sky Captain and the World of Tomorrow. Hollywood, Calif.: Paramount, 2005. Film.

Corbusier, Le. The City of Tomorrow and Its Planning. London: Architectural Press, 1927. Print.

Davis, Mike. "Bunker Hill: Hollywood's Dark Shadow." Cinema and the City: Film and Urban Societies in a Global Context. Ed. Mark Shiel and Tony Fitzmaurice. Oxford: Blackwell, 2001. 33-45. Print.
---. City of Quartz: Excavating the Future in Los Angeles. London; New York: Verso, 1990. Print.

Donald, James. Imagining the Modern City. Minneapolis: University of Minnesota Press, 1999. Print.

Doyle, Arthur Conan, and Sidney Paget. The Original Illustrated Sherlock Holmes: 37 Short Stories plus a Complete Novel, Comprising The Adventures of Sherlock Holmes, The Memoirs of Sherlock Holmes, The Return of Sherlock Holmes and The Hound of the Baskervilles. New York: Castle Books, 2011. Print.

Emmerich, Roland et al. The Day after Tomorrow. [United States]: 20th Century Fox Home Entertainment, 2004. Film.

Fante, John. Ask the Dust. Santa Barbara: Black Sparrow Press, 1979. Print.

---. Dreams from Bunker Hill. Santa Barbara: Black Sparrow Press, 1982. Print.

Frisby, David. Cityscapes of Modernity: Critical Explorations. Cambridge: Polity Press, 2001. Print.

Jackson, Peter et al. King Kong. Universal City, CA: Universal Pictures, 2006. Film.

Johnson, Mark et al. Young Sherlock Holmes. Hollywood, Calif.: Paramount Home Entertainment, 2003. Film.

Pasi, Marco. "The Neverendingly Told Story: Recent Biographies of Aleister Crowley." Aries 3 (2003): 224-245. Print.

Pile, Steve, Christopher Brook, and Gerry Mooney, eds. Unruly Cities? Order/disorder. London and New York: Routledge, 1999. Print. 
Poe, Edgar Allan. The Man of the Crowd. Charlottesville, Va.: University of Virginia Library. Open WorldCat. Web accessed 4 Dec. 2013.

Reisenleitner, Markus. “The Company of Strangers': Urban Cultural Diversity and Colonial Connections in Twentieth-Century Popular Fiction and Cinema." Cartographies of Place: Navigating the Urban. Ed. Michael Darroch and Janine Marchessault. Montréal: McGill-Queen's University Press, 2014. 203-216. Print.

---. "Translating the Past, Digitally: Nostalgia, the City and the Digital Image in Peter Jackson's King Kong (2005) and Baz Luhrmann's Australia (2008)." Historical Textures of Translation: Traditions, Traumas, Transgressions. Ed. Susan Ingram and Markus Reisenleitner. Vienna: Mille Tre, 2012. 175-183. Print.

Ritchie, Guy, Michael Johnson, et al. Sherlock Holmes. Burbank, CA: Warner Home Video, 2010. Film.

Ritchie, Guy, Joel Silver, et al. Sherlock Holmes a Game of Shadows. Burbank, CA: Warner Home Video, 2012. Film.

Ross, Andrew. Strange Weather: Culture, Science, and Technology in the Age of Limits. London; New York: Verso, 1991. Print.

Simmel, Georg. "The Metropolis and Mental Life." The Blackwell City Reader. Ed. Gary Bridge and Sophie Watson. Oxford; Malden, Mass.: Wiley-Blackwell, 2002. 11-19. Print.
Sue, Eugène. The Mysteries of Paris. Ed. le luxe. Boston: C.T. Brainard, 1845. Print.

Vidler, Anthony. The Architectural Uncanny: Essays in the Modern Unhomely. Cambridge, Mass.: MIT Press, 1992. Print.

Yates, Frances. Giordano Bruno and the Hermetic Tradition. Chicago: University of Chicago Press, 1964. Print.

---. The Occult Philosophy in the Elizabethan Age. London; Boston: Routledge \& K. Paul, 1979. Print.

---. The Rosicrucian Enlightenment. London; Boston: Routledge and Kegan Paul, 1972. Print.

\section{Image Notes}

Fig. 1 http://en.wikipedia.org/wiki/ File:Aleister_Crowley,_wickedest_man_ in_the_world.jpg

Fig. 2 Screengrab from Sherlock Holmes

Clips 1 \& 2 From Sherlock Holmes 
Markus Reisenleitner is Associate Professor and Director of the Graduate Program in Humanities at York University, Toronto. His research and publications focus on urban imaginaries, fashion and digital cultures.

Markus Reisenleitner est professeur associé et directeur du programme gradué au Department of Humanities de l'Université York à Toronto. Ses recherches et publications portent sur les imaginaires urbains, la mode, et les cultures digitales.

This article is licensed under a Creative Commons 3.0 License although certain works referenced herein may be separately licensed, or the author has exercised their right to fair dealing under the Canadian Copyright Act. 